\title{
Climate science can't be trumped: a look at how to translate empirical data into political action
}

E. Watts ${ }^{1}$, U. Hoßfeld ${ }^{1}$, G. S. Levit ${ }^{2}$

${ }^{1}$ Jena University, Am Steiger, Jena, 07743, Germany

2 Kassel University, 40, Heinrich-Plett-Str. Kassel, 34109, Germany

For citation: Watts E., Hoßfeld U., Levit G. S Climate science can't be trumped: a look at how to translate empirical data into political action. Vestnik of Saint Petersburg University. Philosophy and Conflict Studies, 2019, vol. 35, issue 1, pp. 145-158. https://doi.org/10.21638/spbu17.2019.112

Although over $97 \%$ of scientists are in agreement regarding the occurrence, cause and consequences of climate change, studies have found that less than $50 \%$ of Americans believe that climate change is caused by human activities and that Americans remain greatly divided regarding the causes, urgency and solutions to the climate crisis. The gravity of the situation only appears to be growing as recent reports have shown that climate change denial is not limited to the United States and that other global citizens also appear to be confused regarding the legitimacy of climate change science data. The prevalence of confusion highlights the dire need for better educational programs and grassroots actions by the scientific and academic communities. However, the path from 'data' to citizen action is hardly a direct one, and thus the engagement of the climate science community (ENGOs and other boundary organizations, academia, governments) in education will not be simply one of 'getting the word out'. That community will need to grapple with the complex socio-epstemic space that lies between scientific knowledge production and citizens' participatory engagement with climate change policies. This paper outlines some aspects of that complexity and suggests ways how certain types of knowledge dissemination as such, which lead to increased scientific literacy, can contribute to increased citizen action.

Keywords: climate change, climate-science denial, nature of science, science education, public understanding of science.

\section{Introduction}

Anthropogenic climate change is already affecting our planet and will continue to do so for many generations. An ever-growing mass of data and consensus within the scientific community shows that burning fossil fuels and other human actions are responsible for the majority of recent warming trends and extreme weather conditions [1-4], and an immediate global effort is required to reduce and reverse these detrimental activities. Yet, this mass of data is only useful if it is translated into action and such a movement from data to action requires an understanding of the data and responsible individuals to create and comply with climate-friendly policies. It is therefore imperative that citizens across the globe develop climate literacy as they effect the global climate and the efficacy of environmental policies through their roles as employees, voters, consumers, etc. [1].

Unfortunately, a universal level of climate science literacy has not yet been accomplished. Here we define climate literacy not only as knowledge about the overall consensus

(C) Санкт-Петербургский государственный университет, 2019 
on climate change but also the ability to accept this data and the willingness to change personal behaviors or consumer choices in order to assist in the global mitigation of climate change. If climate illiteracy was simply caused by a lack of knowledge, the solution would be easy - provide more information - but instead this situation is complicated by the fact that individuals continue to actively deny the truth of anthropogenic climate change regardless of the abundancy of available data on the subject and they do not feel an urgency to become involved in decarbonization. As will be discussed, this habit of denial is driven not by a lack of information but by economic interests, ideologies, conflicting personal interests, party identification, etc. and thus as we attempt to increase climate literacy, we will have to drop our expectations of seeing immediate behavioral alterations and realize that real change is likely to occur within the upcoming generation.

This active choice of the economy over ecology can be seen most clearly and heard most loudly from US President Donald Trump. Trump outright denies the validity of climate change data and the US responsibility to proactively address climate concerns. His actions and remarks have caused great concern for the global scientific community especially since meeting the proposed B1 emissions path would require a fundamental transformation of the global energy system by the end of the century and if any of the major emitters delay in the decarbonization of their economies, it will be hard to reach the international targets [5]. The degree of concern has only mounted since Trump has begun to reverse many of the climate change policies set into action during Obama's presidency [6]. While Trump's 2017 executive orders to reverse Obama's policies on climate and water pollution will not be implemented immediately, they do send a clear message that the new administration is determined to promote economic activity (i.e. fossil fuel productivity) even when those activities directly collide with environmental safeguards ${ }^{1}$. Even more worrisome is that Donald Trump's words and actions are representative of the voters who voted him into office and reflect the large degree of climate science denial within the American public.

While this type of widespread climate science ignorance is usually believed to be unique to the US, recent studies have shown that similar confusion exists in many other countries as well. When looking at the 2014 "Global Trends" study conducted by the UKbased market research firm Ipsos MORI (Figure 1), we see that while the US and China are usually placed close together in the run for the highest emitters of $\mathrm{C} 02$, they are on opposite sides of the spectrum when it comes to understanding the effects of $\mathrm{C} 02$ emissions on the environment. Located towards the bottom of the list, together with the US, is Great Britain and Australia, leading some authors ${ }^{2}$ to humorously propose that climate change science denial is linked to speaking English but Canada's position above Japan and Russia caused an obvious breakdown in the theory. Instead it appears that the root of denial in the US and other countries as Australia and Britain is linked to the fact that all of these countries are also hosts of large, privately owned oil, coal, and mining companies, which

1 “Trump to Roll Back Obama's Climate and Water Rules Through Executive Order", available at: https://www.washingtonpost.com/news/energy-environment/wp/2017/02/20/trump-to-roll-back-obamasclimate-water-rules-through-executive-action/?noredirect=on\&utm_term=.d1fae3d3f086 (Accessed 22 April 2018).

${ }^{2}$ See "Global Warming Denial Linked To... Speaking English?" by Chris Mooney, available at: https://www.huffingtonpost.com/2014/07/23/global-warming-denial-english_n_5614053.html?utm_hp_ ref=pt\&src=sp\&comm_ref=false (Accessed 23 April 2018). 
To what extent do you agree or disagree? The climate change we are currently

seeing is largely the result of human activity

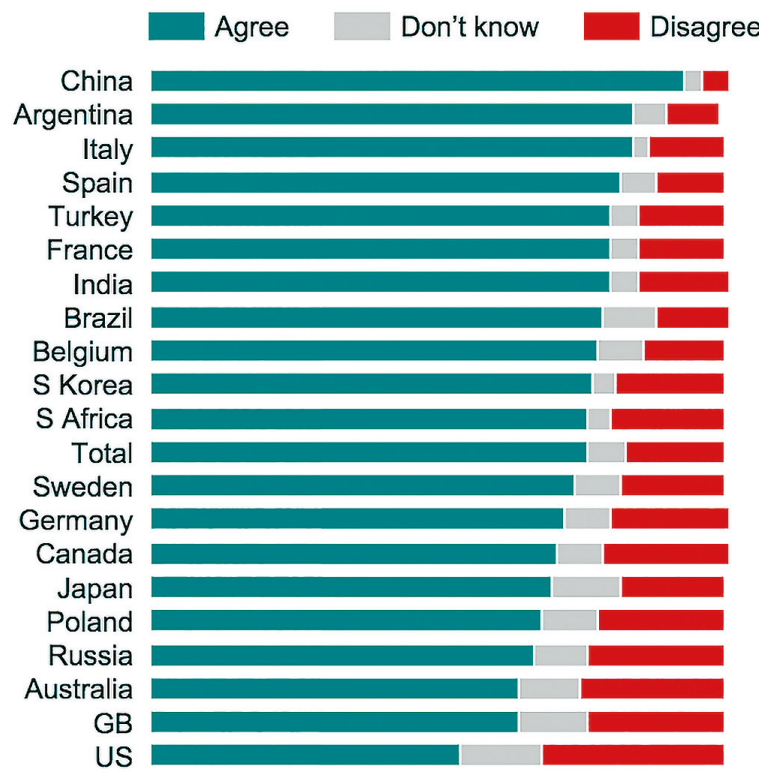

Fig. 1. Results from Global Trends show that climate change denial is not a unique phenomenon to the US

would arguably have the most to lose economically through international and national restrictions on carbon emissions [7].

In fact, some studies have shown that the wide-spread "confusion" regarding climate change in the US has actually been actively propagated by policy makers and the media in the US, which frequently assert that the causes of current global warming and climate change are still highly uncertain [3; 8]. Just as large think-tanks, such as the Discovery Institute, have promoted confusion regarding the evidence for evolution within the general public through their "teach the controversy" campaigns [9], there are also special interest groups who actively encourage confusion regarding climate change [10-12]. In fact, $90 \%$ of American conservative think-tanks involved in environmental issues advocate anthropogenic climate change denial and have manufactured campaigns designed to create doubt about the science behind climate change in order obscure the scientific consensus and data on the subject [13]. It is thus not surprising that ideology and party identity play a very strong role in whether or not individuals accept that humans are responsible for climate change (Figure 2).

Climate science deniers use a range of arguments from denying or questioning the existence of anthropogenic climate change, its magnitude, and the rate of its progress to the risks it presents, the integrity of climate scientists, and the worth of mitigation attempts [14]. One such anti-climate science organization is the American Energy Alliance 
Relative Strength and Statistical Significance of Factors Influencing Views on Controversial Issues

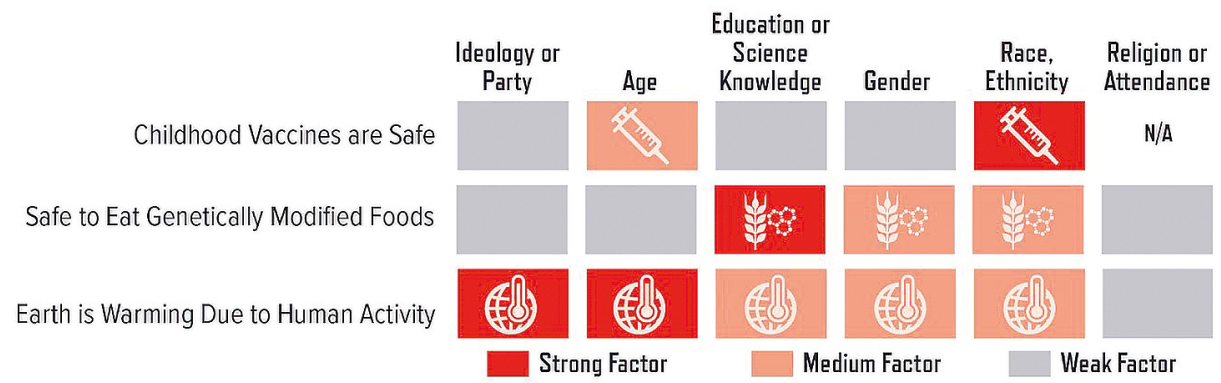

SOURCE: Cary Funk and Lee Rainie, Americans, Politics and Science Issues, Pew Research Center (July 1, 2015; survey conducted August 2014).

From Perceptions of Science in America (American Academy of Arts \& Sciences, 2018)

Fig. 2. The impact of ideology and party identification on an individual's view regarding anthropogenic climate change

who, although they claim to have no political affiliation, issued a statement on the success ful election of Trump stating that “...President-elect Trump's victory presents an opportunity to reset the harmful energy policies of the last generation. He has laid out an energy plan that puts the needs of American families and workers first... We were among the first organizations to endorse President-elect Trump and we're excited to work with his administration to put forth energy policies that will deliver affordable energy to American families, invigorate the economy, and create more opportunities for future generations ${ }^{3}$."

The motivation behind such arguments and propaganda is usually an attempt to hinder and prevent policies that would reduce the emission of greenhouse gases [3], again pointing to the link between large, privately-own fossil fuel organizations and wide-spread denial of climate science. As long as special interest groups are devoted to preventing ecologically friendly measures, think-tanks will continue to produce materials to promote climate change conspiracy thought. Here we argue that the global academic community's action is required to address this problem. As well-funded think-tanks continue to perpetuate climate-change confusion, the global academic community must become more actively involved in perpetuating scientific literacy - particularly climate science literacy - as an understanding and acceptance of climate change data is necessary for that data to be translated into policies and actions.

\section{Climate Change Denial in the US}

The global consensus regarding the anthropogenic climate change and the necessity to act was highlighted as nations all over the world ratified the Paris Act [15]. Yet, despite the consensus within the global community of scientists and politicians regarding the fact that climate change is caused by humans and that immediate action is needed to ameliorate the situation, in June 2017 Trump announced that the US will be pulling out of

${ }^{3}$ Available at: http://americanenergyalliance.org/2016/11/09/aea-issues-statement-trump-victory/ (accessed 23 April 2018). 


\section{About half of Americans say Earth is warming due to human activity}

$\%$ of U.S. adults saying climate change is mostly due to human activity/mostly due to natural patterns/there is no solid evidence that Earth is getting warmer

- Because of human activity

- Because of natural patterns

$\square$ There is no solid evidence

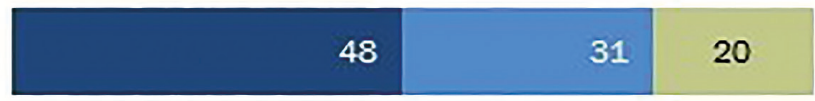

Note: Beliefs about climate change include those who "lean "toward each response. Thosewho did not give an answer are not shown. Source: Survey conducted May 10-June 6, 2016.

"The Politics of Climate"

\section{PEW RESEARCH CENTER}

Fig. 3. Results of PEW study showing that less than half of all Americans believe that humans are responsible for climate change

the Paris agreement in an attempt to renegotiate the terms of the agreement. Trump's announcement was met with applause by a small crowd gathered on the White House lawn and reflects the fact that less than $50 \%$ of Americans actually believe that climate change is caused by human activities (Figure 3) as shown in the 2016 Pew Research Report [4].

American's denial of climate change is very alarming to citizens across the world, especially in light of the fact that the US is well-known as the world's second largest emitter of $\mathrm{C02}$ (Figure 4) and that research has shown that strenuous action by all major emitters is required to achieve global emission goals set forth by the Paris agreement ${ }^{4}$. Although we cannot expect any comprehensive national climate legislation to be passed by the Trump administration, there is cause for optimism as a variety of policies and measures that have been put into place voluntarily in the US at federal, state and local levels such as the Federal Energy Regulatory Commission, California’s Global Warming Solutions Act (AB 32) and the Regional Greenhouse Gas Initiative. Also, a number of voluntary national organizations were created through grassroots cooperation, such as the Carbon Disclosure Project, the US Mayors Climate Protection Agreement and the American College and University Presidents' Climate Commitment, etc. ${ }^{5}$

The fact that action is being taken despite loud cries of denial coming from Trump's administration is encouraging. In fact, it may even be possible that the US will meet its Paris emissions target with or without the agreement as the economy is quickly moving away from energy sources like coal in favor of more sustainable sources of energy. California and other states have also pledged to pick up the slack caused by Trump's withdrawal

\footnotetext{
${ }^{4}$ Available at: //nca2014.globalchange.gov/report/response-strategies/mitigation (Accessed 26 April 2018).

${ }^{5}$ For a complete overview of these programs please see the National Climate Assessment. A full report of mitigation strategies, available at: http://nca2014.globalchange.gov/report/response-strategies/mitigation
} 


\section{Top 10 Emitters}

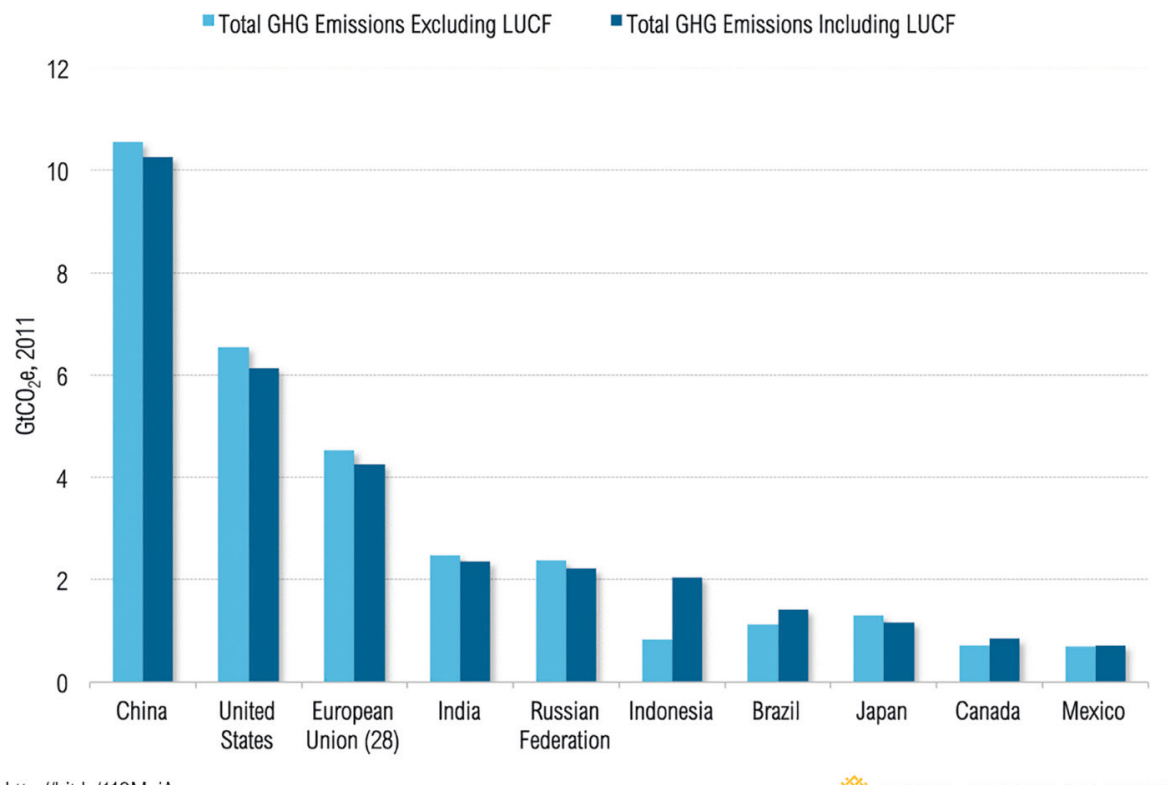

http://bit.ly/11SMpjA

WORLD RESOURCES INSTITUTE

Fig. 4. Data from the World Resource Institute showing that the US is the world's second largest emitter of greenhouse gasses both when including and excluding land-use change and forestry data

from the Paris agreement by instituting their own environmental restrictions ${ }^{6}$. Also, in direct response to Trump's June 2017 announcement of the US' withdrawal from the Paris Accord, a new national campaign among American businesses, mayors and universities were initiated, called "We Are Still In". Since June 2017, thousands of mayors, CEOs and other leaders across the US have signed this open letter to show their continued commitment to the Paris Agreement. The Declaration reads:

An open letter to the international community and parties to the Paris Agreement from U.S. state, local, and business leaders:

We, the undersigned mayors, county executives, governors, tribal leaders, college and university leaders, businesses, faith groups, cultural institutions, and investors are joining forces for the first time to declare that we will continue to support climate action to meet the Paris Agreement.

In December 2015 in Paris, world leaders signed the first global commitment to fight climate change. The landmark agreement succeeded where past attempts failed because it allowed each country to set its own emission reduction targets and adopt its own strategies for reaching them. In addition, nations - inspired by the actions of local and regional governments, along with businesses - came to recognize that fighting climate change brings significant economic and public health benefits.

The Trump administration's announcement undermines a key pillar in the fight against climate change and damages the world's ability to avoid the most dangerous and costly effects of climate change. Importantly, it is also out of step with what is happening in the United States.

${ }^{6}$ Available at: https://www.nbcnews.com/politics/white-house/here-s-what-happens-if-trump-leavesparis-climate-agreement-n766761 (Accessed 27 April 2018). 


\section{Emissions Intensity of Top 10 Emitters}

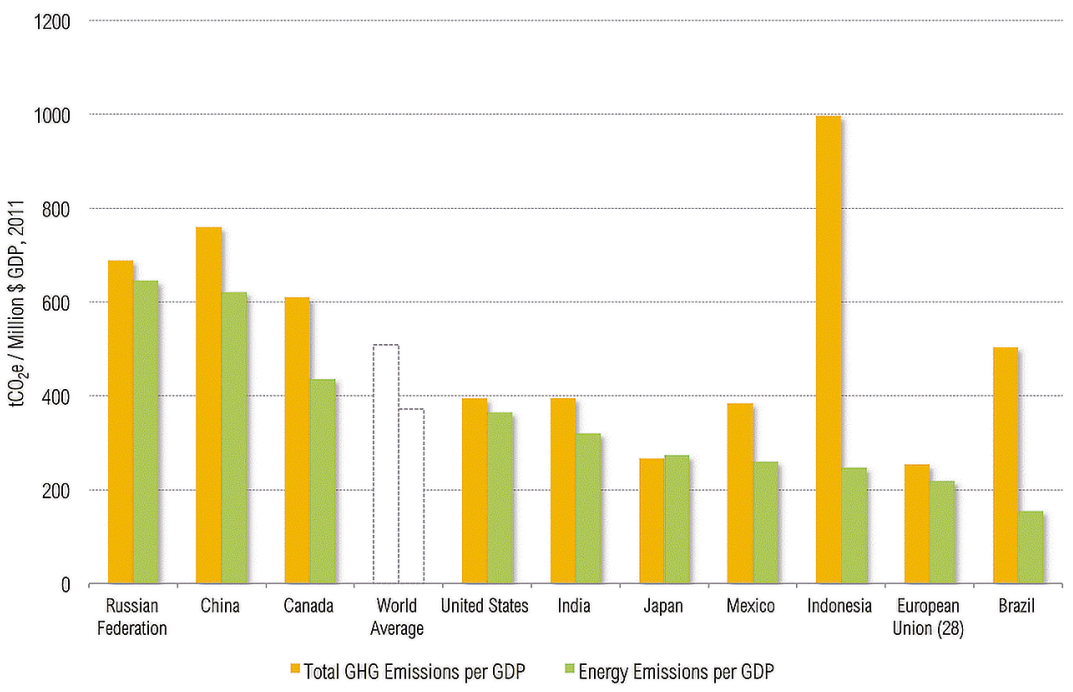

hittp//bit.ly/11SMpjA

NO WORLD RESOURCES INSTITUTE

Fig. 5. Data from the World Resources Institute show that the United States is below the world average in terms of emissions intensity

In the U.S., it is local, tribal, and state governments, along with businesses, that are primarily responsible for the dramatic decrease in greenhouse gas emissions in recent years. Actions by each group will multiply and accelerate in the years ahead, no matter what policies Washington may adopt.

In the absence of leadership from Washington, states, cities, counties, tribes, colleges and universities, businesses and investors, representing a sizeable percentage of the U.S. economy will pursue ambitious climate goals, working together to take forceful action and to ensure that the U.S. remains a global leader in reducing emissions.

It is imperative that the world know that in the U.S., the actors that will provide the leadership necessary to meet our Paris commitment are found in city halls, state capitals, colleges and universities, investors and businesses. Together, we will remain actively engaged with the international community as part of the global effort to hold warming to well below $2^{\circ}$ and to accelerate the transition to a clean energy economy that will benefit our security, prosperity, and health.

This locally-driven trend away from carbon-heavy energy sources is reflected in recent studies which have shown that while the US may be the second largest producer of $\mathrm{CO} 2$ emissions, it is below the world average in terms of emissions intensity (Figure 5).

What this trend also shows us is the effect and power of local leaders banning together. While Trump's anti-scientific declarations and reversal of many climate-friendly policies remain alarming, the grassroots actions and cooperation among American business, academic, political and faith leaders offers cause for optimism. This type of cooperation is also possible at an international level, for instance among university presidents. In the US, we have seen that 679 higher education institutions have already signed the American College and University Presidents' Climate Commitment, pledging to develop 
plans to achieve net-neutral climate emissions through campus-wide policy and resource changes ${ }^{7}$. These types of organizations and commitments act as models of what is possible at a local level. As scientists and academics have the easiest access to primary research and data regarding climate science, we have the highest duty to turn this knowledge into action and help increase general climate literacy through our teaching.

\section{In Search of Solutions}

One potential means of addressing the climate science denial would be the implementation of a national climate change education program. One such program was proposed in the US in 2016 by Senators Honda and Markey entitled "Climate Change Education Act" [16]. The implementation of a centralized program would have been a great step towards climate change literacy in that it would have been a major step towards committing to better education about climate change and it would have also sent a clear message to the public about the certainty of anthropogenic climate change and the urgency to act as a united nation within a global community. Unfortunately, no action has been taken on this program since June 2016 after it was read and referred to the Committee on Commerce, Science, and Transportation (https:/www.congress.gov/bill/114th-congress/ senate-bill/3074/actions, Accessed 24 April 2018), nor can there be any real hope of such an act being enacted under the current administration. The act does, however, provide a useful model for a centralized education program which could be centrally adopted by another national government or enacted at a state-level within the US.

The Climate Change Education Act would have specifically authorized the National Oceanic and Atmospheric Administration (NOAA) to establish an educational program which should provide nationwide formal and informal learning opportunities for all ages so that Americans can better understand climate change and its effects on the environment as well as its effect on social and economic systems. This would be a crucial step in meeting one of the goals set in 1982 by the National Science Teachers Association (NSTA) that science education should enable students not only to understand how science, technology, and society are intrinsically related, but also how to use this knowledge in everyday decision making [17]. International agencies, such as the United Nations Educational, Scientific and Cultural Organization (UNESCO), have also already recognized the need for better education about climate change and have consequently created educational programs such as the Education for Sustainable Development (ESD) as part of their Global Action Programme (GAP).

But the implementation of climate science programs alone cannot be seen as the answer. Studies have clearly shown that climate change denial is not caused by a lack of information but by preconceptions that conflict with scientific data. These misconceptions can be obstinate and specifically focused types of instruction are needed to address these misconceptions and to help individuals/students adopt mental models that are scientifically accurate and not anti-scientific in nature $[18 ; 19]$, but first, we must understand and address the nature of denial and the public's understanding of science.

${ }^{7}$ Available at: http://nca2014.globalchange.gov/report/response-strategies/mitigation (Accessed 26 April 2018). 


\section{The nature of denial}

First and foremost, we must differentiate between healthy skepticism and anti-scientific attitudes. Scientific knowledge is not static - continuous advancements in scientific technology lead to an increasingly rapid succession of knowledge about the natural world - and for this reason, it is important that individuals understand how scientists come to a consensus. It is, of course, also necessary that individuals learn to question and critique what is taught to them during science lessons or what is communicated to them through the media [20]. Yet, we must look at where the public is receiving its information and what forms of questioning are occurring, because it is vitally important to make a distinction between questioning based on scientific curiosity and denial based on preconceptions, economic interests or party membership. Jacques et al. proposed categorizing denial according to four key themes: "those who (1) deny the seriousness of environmental problems and dismiss scientific evidence documenting them, (2) question the importance and wisdom of regulatory policies to address them, (3) endorse an anti-regulatory/anticorporate liability position, and (4) consider environmental protection to threaten Western progress"8. This type of rejection of data cannot be confused with healthy skepticism. Scientists are skeptical - in fact, skepticism is a key component of scientific discovery but the rejection of scientific data is simply a form of deliberate ignorance.

This type of ignorance is only hardened through the public's choice of information channels. Studies from 2002 made it clear that the majority of public does not get their information directly from climate scientists or scientific journals but instead inform themselves about this complex issue via intermediary sources, predominantly the mass media that presents various opinions using language and graphics that are easy to digest [21]. What this means is that the majority of the public's knowledge and understanding of climate change has been almost entirely indirect, informal and mediated [19]. This fact is very concerning as it has been shown that certain media channels, including many websites, are devoted to discrediting climate change and thus act as ideal conduits for spreading contrarian arguments [22]. These types of sources are not only easily accessible but also easily and quickly shared to audiences that are predisposed to accepting and supporting such anti-scientific arguments.

So, what can we do as an academic community to address these issues? Two means of loosening the grip of anti-scientific thought patterns is to (1) offer more education and explanation regarding the nature of science and (2) to communicate climate change in more personal and direct means. These are two types of actions that the academic community can take on with ease. Two key further strategies are recommended. First, it is possible for us to get involved in direct communication with the public and make sure that we are offering lessons on climate change that are more local, personal and incorporate teachings on the nature of science. Furthermore, we can engage with one another as an international community in order to turn climate change data into action at a university or department level.

\footnotetext{
8 [13]. Summarized in [7].
} 


\section{Means of counteracting climate change denial as an international academic society}

Simply presenting data on climate change is not enough to effect climate science literacy. As stated: climate change denial is not caused by a lack of information but by preconceptions that conflict with scientific data. Thus, it will be necessary to teach general scientific literacy concepts in order to help uproot anti-scientific attitudes. We can do this (1) by teaching about the nature of scientific exploration and how scientists come to a consensus and (2) by reframing climate change science as a form of "risk management" thus circumventing the "controversy" in order to directly discuss what the local dangers are and how they can be ameliorated.

Education with a focus on the nature of science: One of the major ways that academics can directly improve scientific literacy and thus climate science literacy is to educate students and the public about the general nature of scientific exploration. In this way, they can better understand how scientists around the world have come to a consensus about anthropogenic climate change. By addressing the nature of science in connection with lessons on climate change, individuals also have the opportunity to better understand the value of science as a central tool in explaining and understanding the natural world. They can thus better appreciate how scientists use observation, empirical data and other evidence to develop working theories that may change over time as new data is gathered. This newly gained knowledge, not only about climate change but also about the scientific endeavor, may also enable students to better judge which sources are the most reliable with regard to statements about scientific consensus. Understanding the means by which scientists come to understand the natural phenomenon and also learning to distinguish between reliable and unreliable sources may also allow students to more easily understand the value of climate research.

In this way, individuals can better appreciate how a better understanding of the causes of global warming can help develop policies that alleviate further environmental destruction. Furthermore, a deeper understanding of the effects of climate change can also enhance our ability to anticipate complex issues arising from climate change such as species' responses to climate change. Such knowledge then allows scientists to improve projections and support more informed decisions by policymakers and land managers [23].

Moreover, an appreciation of scientific inquiry will also enable students to integrate the data on climate change into their understanding of the natural world and allow them to see how scientists are not only able to stipulate about the anthropogenic causes of climate change but are also thus capable of making predictions about the long-term effects of climate change. In general, a greater understanding of the scientific data, i.e. the causes or effects of climate change, helps us make more informed decisions and better understand the effects of our own behavior. Understanding the nature of scientific discovery has the added benefit that we are better able to understand how these data were gathered, calculated and quantified, thus allowing us to better understand science's role in public discourse. Keith Taber, science education professor, has in fact shown that knowledge about the nature of science is essential as this better prepares individuals to become future scientists, informed citizens and educated members of society [24].

Education with a focus on action and behavioral change: Getting people to become actively involved in the decarbonization of our economies is not easy. According to econ- 
omist John List, Kenneth C. Griffin Distinguished Service Professor of Economics and Chairman of the Department of Economics at the University of Chicago, the problem lies in the immediate costs of mitigation, combined with the fact that the projected benefits are not scheduled to occur for $50,100,150$ or 200 years. So it is difficult to convince a population to make perceived economic sacrifices for an environmental tradeoff that they may not experience in their own lifetime. List believes that it is possible that education and information can change beliefs, but over generations - not overnight. If we want behevioral changes to occur more quickly, then we need focus on motivating our kids now ${ }^{9}$.

This motivation and incentive can come through the emphasis on effects of climate change at a local and personal level and on mitigation measures that offer quicker and more visible results. Here a focus on how climate change effects human health can be very influential as decarburization measures can have immediate and local benefits for human health [5]. This is in stark contrast to the general, global and long-term effects of climate change and it is a concept that individuals comprehend more easily [25].

By focusing on direct effects and local mitigation potential, teaching on climate change can be reframed as of means of "risk management" [19]. Risk management is a concept that the public is readily familiar with through activities in everyday life at school or in the home such as wearing a helmet to reduce the risk of brain damage in case of a bike accident or securing heavy furniture to the wall in case of an earthquake. By reframing climate change discussions into a conversation about risk management it is possible to use these everyday activities to show how it is logical to do things to prevent or mitigate possible risk situations. Thus, instead of presenting the public with a simple regurgitation of data on how humans are a major cause of climate change, it could be beneficial to look at exactly how humans can mitigate climate change danger and how those mitigation efforts could have direct effects on their own health and safety [26]. Information regarding the direct effects on human health can be found in the chapter on human health in the National Climate Assessment, which appears every four years (https://nca2014.globalchange.gov/report/sectors/human-health).

This approach also allows instructors to circumvent the debate and the various denialist arguments over whether or not climate change is caused primarily by humans or if the change is severe enough to result in severe global environmental changes and simply states the benefit of preparing for and preventing potential risks [26]. This reframing of the issue may also allow citizens to more easily accept the legitimacy of scientific consensus as it no longer appears to be a situation of blame and thus they could be more willing to learn about measures that would help diminish global warming, thereby becoming an active participant in the mitigation of global climate change.

When it comes to the mitigation measures that we communicate to the public, we should focus on promoting those behavioral changes that are most likely to occur, i.e. those behaviors which have a higher degree of plasticity and thus more likely to be altered through external factors such as learning. According to Stern, consumer choices, such as the decision to purchase energy-efficient equipment, have not only a larger impact on decarbonization but also have a larger degree of behavioral plasticity than changes to household habits. For example, the purchase of more energy-efficient appliances (behavioral plasticity $80 \%$ ) has the potential of reducing 14.7 metric tons of carbon, while using

${ }^{9}$ Full transcript available at: http://freakonomics.com/2014/07/17/why-you-should-bribe-your-kidsfull-transcript/ (Accessed 30 April 2018). 
a cooler temperature to do laundry (behavioral plasticity $35 \%$ ) only leads to a reduction of 0.5 metric tons of carbon [27].

These type of behavioral changes and consumer choices can, of course, be supported through governmental policies such as those instated in desert regions facing immediate water-shortage. In the city of El Paso, Texas, for example, the government created a number of economic incentives to address the severe lack of ground water and ever-increasing urban expansion. Citizens were given monetary benefits for replacing their toilets and showerheads with low-flow variations and home owners are also offered financial advantages for xeriscaping their property, i.e. the removal of lawns in favor native plants, gravel or artificial lawns [28].

\section{Conclusion}

Wide-spread climate change denial is actively perpetuated by propaganda, economic interests, ideologies and party identification. This means that we cannot expect a simple inflow of facts to be quickly translated into effective environmentally-friendly policies and behavioral changes. While this type of climate change denial is actively promoted, especially by national leaders, we cannot be deterred. As members of the academic community we have a unique ability and duty to counteract this anti-scientific trend as we (1) have the access and the ability to understand the most recent and convincing data on climate change, (2) often have access to communication or teaching opportunities where these data can be shared. Moreover, members of an academic establishment also have the ability to become active in translating data into action or participating in cooperation with similar institutions.

While we cannot expect immediate results, effective communication regarding climate science could cause a general shift in the public's understanding of climate change over time as it could help deconstruct mental modes that prevent individuals from being able to integrate scientific findings into their own particular worldview. We must acknowledge that due to the political nature and polarization of the climate change issue that it may be difficult to bridge the gap between adult climate change denialists and science advocates, but in the meantime, it is important that academics are not swayed or discouraged by climate change denial but instead remain steadfast in their advocacy of science and action.

\section{References}

1. Branch, G., Rosenau, J., and Berbeco, M. (2016), "Climate education in the classroom: cloudy with a chance of confusion”, Bulletin of the Atomic Scientists, vol. 72, no. 2, pp. 89-96.

2. Cook, J., et al. (2013), "Quantifying the consensus on anthropogenic global warming in the scientific literature”, Environmental Research Letters, vol. 8, no. 2, pp. 1-7.

3. Oreskes, N. (2004), "The Scientific Consensus on Climate Change", Science, vol. 306, no. 5702, pp. 1686.

4. Funk, C. and Kennedy, B. (2016), “The Politics of Climate”. PewResearchCenter, available at: http:// www.pewinternet.org/2016/10/04/the-politics-of-climate/ (Accessed 2 July 2018).

5. Melillo, J.M., Richmond, T. T.C., and Yohe, G. W., eds (2014), Climate Change Impacts in the United States: The Third National Climate Assessment. U.S. Global Change Research Program, available at: https:// nca2014.globalchange.gov/report/our-changing-climate/introduction (Accessed 2 July 2018).

6. Reardon, S., et al. (2016), "The ulimate experiement: How Trump will handle science", Nature News, Nature Publishing Group, pp. 337-339. 
7. Painter, J. (2011), Poles Apart - The international reporting of climate skepticism, Reuters Insitute for the Study of Journalism, Oxford, UK.

8. Conway, E. and Oreskes, N. (2010), Merchants of Doubt: How a Handful of Scientists Obscured the Truth on Issues from Tobacco Smoke to Global Warming. Bloomsberry Press, London, UK.

9. Meyer, S.C. (2002), "Teach the Controversy", Cincinnati Enquirer, Cincinnati, OH, available at: www. arn.org/docs/meyer/sm_teachthecontroversy.htm (Accessed 2 July 2018).

10. Greenberg, J., Knight, G., and Westersund, E. (2011), "Spinning climate change: Corporate and NGO public relations strategies in Canada and the United States", International Communication Gazette, vol. 73, no. $1-2$, pp. 65-82.

11. Brulle, R. J., Carmichael, J., and Jenkins, J.C. (2012), "Shifting public opinion on climate change: an empirical assessment of factors influencing concern over climate change in the U.S., 2002-2010", Climatic Change, vol. 114, no. 2, pp. 169-188.

12. Pfau, M., et al. (2007), “The Influence of Corporate Front-Group Stealth Campaigns”, Communication Research, vol. 34, no. 1, pp. 73-99.

13. Jacques, P. J., Dunlap, R. E., and Freeman, M. (2008), “The organisation of denial: Conservative think tanks and environmental scepticism", Environmental Politics, vol. 17, no. 3, pp. 349-385.

14. Stern, P.C., et al. (2016), “The challenge of climate-change neoskepticism”, Science, vol. 353, no. 6300, pp. 653-654.

15. United Nations (2016), Paris Agreement, UN Framework Convention on Climate Change, pp. 1-7.

16. Honda, M. and Markey, E. J. (2016), "Our kids learn their ABCs in school. But why not climate change? The classroom is the right place to start educating our citizens about the greatest challenge they will face", The Guardian, available at: https:/www.theguardian.com/commentisfree/2016/sep/28/climatechange-education-act-noaa-school-classrooms (Accessed 1 July 2018).

17. Blanco-López, Á., et al. (2015), "Key aspects of scientific competence for citizenship: A Delphi study of the expert community in Spain", Journal of Research in Science Teaching, vol. 52, no. 2, pp. 164-198.

18. National Research Council (2005), How students learn: History, mathematics, and science in the classroom, Donovan, M. S. and Bransford, J. D., eds, National Academies Press, Washington, DC, USA.

19. Weber, E. U. and Stern, P.C. (2011), "Public understanding of climate change in the United States", American Psychologist, vol. 66, no. 4, pp. 315-328.

20. Taber, K. S. (2017), "Beliefs and Science Education", in Taber, K. S. and Akpan, B., eds, Science Education, Sense Publishers, Rotterdam, The Netherlands, pp. 53-67.

21. Soroka, S. N. (2002), "Issue Attributes and Agenda-Setting by Media, the Public, and Policymakers in Canada", International Journal of Public Opinion Research, vol. 14, no. 3, pp. 264-285.

22. Hamilton, L. C. (2010), "Education, politics and opinions about climate change evidence for interaction effects", Climatic Change, vol. 104, no. 2, pp. 231-242.

23. Urban, M., et al. (2016), "Improving the forecast for biodiversity under climate change", Science, vol. 353 , no. 6304 , pp. 1113 .

24. Taber, K. S. (2017), "Reflecting the Nature of Science in Science Education", in Taber, K. S. and Akpan, B., eds, Science Education, Sense Publishers, Rotterdam, The Netherlands, pp. 23-37.

25. Nemet, G. F., Holloway, T., and Meier, P. (2010), "Implications of incorporating air-quality co-benefits into climate change policymaking", Environmental Research Letters, vol. 5, no. 1, pp. 014007.

26. Watts, E. (2019), “Teaching Climate Science to Increase Understanding and Receptivity", The American Biology Teacher, vol. 81, no. 5.

27. Stern, P. C. (2011), "Contributions to Psychology to Limiting Climate Change", American Psychologist, vol. 66, no. 4, pp. 303-313.

28. Ball, L. S. (2011), "El Paso Weathers Drought, Thanks To Lawn Policy”, available at: https://www.npr. org/2011/08/27/139994008/el-paso-weathers-drought-thanks-to-lawn-policy (Accessed 10 October 2018).

Received: February 17, 2018

Accepted: October 3, 2018

Author's information:

Elizabeth Watts - Dr. rer. nat., PostDoc, elizabeth.watts@uni-jena.de

Uwe Hoßfeld - Dr. rer. nat. habil., Professor.; uwe.hossfeld@uni-jena.de

Georgy Levit - Dr. rer. nat habil., Privatdozent; georgelevit@gmx.de 
Небитая карта науки о климате: взгляд на то, как эмпирические данные преобразуются в политическую активность ${ }^{10}$

Э. Уоттс ${ }^{1}$, У. Хоссфельд ${ }^{1}$, Г.С. Левит ${ }^{2}$

${ }^{1}$ Йенский университет им. Фридриха Шиллера, Федеративная Республика Германия, 07743, Йена, Фюрстенгран, 1

${ }^{2}$ Кассельский университет, Федеративная Республика Германия, 34109, Кассель, Генрих-Плетт Штрассе, 40

Для цитирования: Уотmс Э., Хоссфельд У., Левит Г. С. Небитая карта науки о климате: взгляд на то, как эмпирические данные преобразуются в политическую активность // Вестник СанктПетербургского университета. Философия и конфликтология. 2019. Т. 35. Вып. 1. С. 145-158. https://doi.org/ 10.21638/spbu17.2019.112 (In English)

Хотя более $90 \%$ ученых согласны в том, каким образом обнаруживается изменение климата, каковы причины и последствия этого изменения, исследования выявили, что менее $50 \%$ американцев убеждены, что причиной изменения климата является деятельность человека, и что в американском обществе мнения насчет причин, насущности и способов решения климатического кризиса сильно поляризованы. Серьезность ситуации только нарастает в связи с недавними сообщениями о том, что подобное отрицание климатических изменений не ограничивается лишь Соединенными Штатами и что другие члены мирового сообщества затрудняются признать правомерность данных, которыми располагает на этот счет наука. Преобладание скептиков подчеркивает крайнюю необходимость проведения академическим сообществом улучшенных образовательных программ и акций среди широких масс населения. Однако путь от «данных» к гражданской акции вовсе не является прямым; таким образом, вовлеченность общества науки о климате (ENGO - неправительственной организации по охране окружающей среды, и других смежных организаций, академий, правительства) в образование будет состоять не только в том, чтобы «получить свое слово». Задачей такого рода общества будет борьба за сложную общественно-эпистемологическую область, которая располагается между результатами производства научных знаний и участием самих граждан в политике по изменению климата. В статье описываются некоторые аспекты такого рода затруднений и предлагаются способы, которыми определенные виды распространения научных знаний, повышающие массовую образованность, могут внести свою лепту в увеличение гражданской активности.

Ключевые слова: изменения климата, непризнание науки о климате, природа науки, научное образование, общественное понимание науки.

Статья поступила в редакцию 4 апреля 2018 г.; рекомендована в печать 3 октября 2018 г.

Контактная информация:

Элизабет Уоттс - д-р естественных наук, постдок; elizabeth.watts@uni-jena.de Уве Хоссфельд - д-р естественных наук, д-р филос. наук, проф.; uwe.hossfeld@uni-jena.de Георгий Семенович Левит - д-р биол. наук, приват-доцент; georgelevit@gmx.de

${ }^{10}$ В оригинальном англоязычном названии - игра слов: to trump - «козырять, заходить с козырей» (в карточной игре) и фамилия действующего Президента США Д. Трампа. - Примеч. ред. 